\title{
Trophodynamics of the Fish Valenciennellus tripunctulatus. I. Vertical Distribution, Diet and Feeding Chronology
}

\author{
Thomas L. Hopkins and Ronald C. Baird \\ Department of Marine Science, University of South Florida, 830 First Street South, St. Petersburg, Florida 33701, USA
}

\begin{abstract}
The adult and juvenile life stages of the small $(\sim 25 \mathrm{~mm})$ zooplanktivorous mesopelagic fish Valenciennellus tripunctulatus (Esmark) are found at depths of $200-600 \mathrm{~m}$ throughout the diel period. Average population density was estimated to be $5 \mathrm{fish}\left(10^{4} \mathrm{~m}^{3}\right)^{-1}$ and the maximum density recorded was 11 fish $\left(10^{4} \mathrm{~m}^{3}\right)^{-1}$. Copepods constituted $95 \%$ of all food items identified and Pleuromamma was the principal forage genus, contributing $31 \%$ and $56 \%$ to numbers and biomass of food items, respectively. Ontogenetic changes in diet were observed, the percentage of larger copepods increasing in the diet with increasing fish size. Food items were primarily $1-4 \mathrm{~mm}$ in size. The relationship between number of prey in stomachs and fish length was not statistically significant whereas prey biomass was highly correlated with fish size. A diunal feeding pattern was apparent, the period of most active feeding being $1200-2200 \mathrm{~h}$. Daily ration, as estimated with regression equations, varied with fish size and increased more slowly in relation to standard length than to fish biomass. Maximum estimated daily ration as a percentage of body weight was $5.6 \%$ for $15 \mathrm{~mm}$ fish and $3.7 \%$ for $30 \mathrm{~mm}$ individuals. The average number of prey items in fishes taken during the period of active feeding was 9 while maxima varied between 14 and 24
\end{abstract}

\section{INTRODUCTION}

Midwater fishes are prominent micronektonic components of oceanic ecosystems, yet only recently has effort been directed towards investigating their feeding ecology. The trophodynamics of midwater fishes inhabiting the large oceanic 'gyre' systems at tropicalsubtropical latitudes is of particular interest since these regions exhibit a number of unique ecological characteristics as well as cover much of the globe. Tropical-subtropical gyre systems appear seasonally stable, resource-poor, and have a low level of primary production. Because of their hydrographic stability ideas concerning gyre ecosystem structure, trophic organization and energy flow are generally well advanced (Vinogradov, 1962; Ryther, 1969; Vinogradov et al., 1972; Steele, 1974; Sheldon et al., 1977; McGowan, 1977; McGowan and Walker, 1979; and others). The actual mechanisms of energy flow are, on the other hand, not well understood and knowledge of trophic pathways in terms of specific predator-prey relationships, particularly at the secondary and tertiary levels. is relatively scant.
In this first paper of a series, we consider data on the vertical distribution, diet composition and feeding chronology of the zooplanktivorous mesopelagic fish Valenciennelus tripunctulatus (Esmark), a characteristic species of tropical-subtropical 'gyre' regions (Fig. 1). We examine various characteristics of the diet with regard to ontogeny and develop several estimates of the daily ration of individuals in the population.

\section{METHODS}

Fish collections were made with $1.8 \times 1.8 \mathrm{~m}$ and 1.8 $\times 3.6 \mathrm{~m}$ modified closing Tucker trawls of $1.1 \mathrm{~cm}$ (stretched) mesh (see Hopkins et al., 1973; Hopkins and Baird, 1975). Tucker trawls were fitted with messenger-actuated opening-closing mechanisms. Multiconductor hydro-wire was used for tows designated $(\mathrm{M})$ and $(\mathrm{C})$ in Table 1. For these tows power was fed down to a Teledyne Taber Model 200 pressure transducer attached to the net so that depth could be monitored continuously on deck. Depth was also recorded 


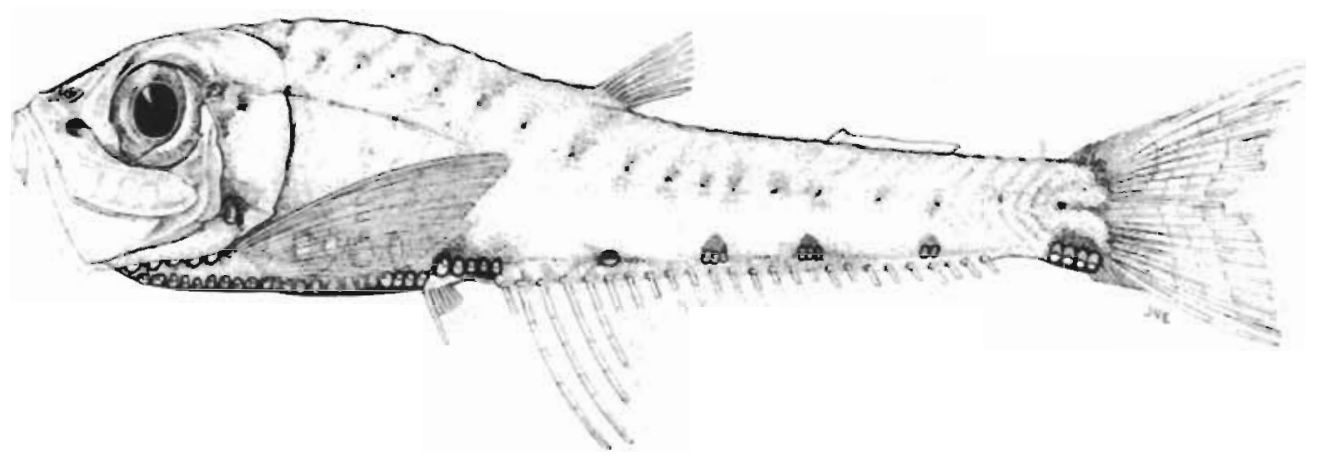

Fig. 1. Valenciennellus tripunctulatus (Esmark). (After Weitzman, 1974)

for all tows by means of a Benthos time depth recorder attached below the release apparatus.

The volume of water filtered was measured by means of a TSK flow meter attached adjacent to the tow bar (Hopkins et al., 1973). The flow meter recorded only when the net was open. An angle of $45^{\circ}$ to the vertical was used in calculating volume filtered, based on observations by divers of the towing attitude of the trawl at shallow depths at trawling speeds of two knots.

A series of 7 plankton tows -3 day and 4 night tows were taken between $7-12$ June, 1976 , at $27^{\circ} \mathrm{N} 86^{\circ} \mathrm{S}$. The tows were of 90-120 min duration and at $300-350 \mathrm{~m}$, the depth zone of maximum population density for Valenciennellus tripunctulatus. The nets, of a modified Tucker design, were inserted in the mouth of the midwater trawl and were closed simultaneously with the larger trawl (Hopkins and Baird, 1975). Plankton nets were fitted with a General Oceanics digital flowmeter which was cross calibrated against the TSK meter on the trawl. Plankton nets had a cross sectional area of $0.2 \mathrm{~m}^{2}$ and a mesh aperture of $162 \mu \mathrm{m}$. Samples were preserved in $5 \%$ buffered formalin.

Trawl catches were initially preserved in $5 \%(\mathrm{~V} / \mathrm{v})$ formalin and later transferred to $50 \%$ isopropyl alcohol. Fish were measured to the nearest millimeter standard length (SL). Other morphometric characters (e.g. jaw width and gape) of selected individuals were measured to the nearest $0.1 \mathrm{~mm}$. For diet analysis, the entire digestive tract was removed. The stomach was defined as the thick, muscular, pigmented anterior section of the digestive tract extending from a short distance posterior to the esophageal opening into the branchial chamber to the origin of the intestine; the intestine included the thin-walled, non-pigmented remainder of the digestive tract. Intestinal caecae were not routinely analyzed because a number of examinations revealed little recognizable food debris.
Contents of digestive tracts were identified, usually to genus, counted, and prey length measured to the nearest $0.1 \mathrm{~mm}$. Diet items included copepods, ostracods, euphausiids, amphipods and chaetognaths. Copepods were measured from the anterior end of the metasome to the tip of the furcae, exclusive of spines and bristles. Euphausiids were measured from the anterior end of the eyes to telson tip, and amphipods from the anterior end of the eye to either telson tip or the end of the uropods depending which was longer. Total valve and body lengths were recorded for ostracods and chaetognaths, respectively. Separate records were kept for stomach and intestinal contents. Identifications and counts for stomach contents were considered more reliable than those for intestinal contents because of the advanced state of digestion of food in the latter. All food items in stomachs were subjectively classified according to state of digestion using a 5 category ranking system where the freshest prey was assigned Category 1.

Biomass of individual food items was estimated from length-dry weight regressions for common prey species, or a regression curve from a taxon of similar morphology for rarer items. The size-dry weight regressions were based on preserved plankton with a salt content of 2-7\% dry weight (Hopkins, 1971). These biomass estimates were not necessarily precisely equivalent to dry weight of living material as some losses of organic matter and salts may have resulted from storage in preservatives. For example, Durbin and Durbin (1978) reported a $29.5 \%$ loss of dry weight from Acartia clausi and Omori (1978) a loss in excess of $30 \%$ of the organic matter in Calanus sinicus preserved in buffered formalin. Conversely, Mullin and Evans (1974) found no carbon losses from formalin preserved Acartia tonsa and Paracalanus parvus. Variations in results - as Durbin and Durbin, and Omori suggest - stem from differences in species, duration of 
storage, buffering and rinsing procedures. In the present study plankton size-weight regressions were based on material preserved for periods in excess of the 1 to 2 months (Omori, 1978) required for organic matter in plankton to stabilize at its minimum level, hence losses undoubtedly occurred.

Plankton organisms in aliquots were identified, enumerated and measured for length. When available, 10 or 20 of each type (usually genus) of prey were measured depending on size variability within a given type. Crustaceans other than copepods were measured from the anterior end of the metasome (end of eyes when present) to the posterior end of the abdomen (usually the telson). For soft-bodied forms such as chaetognaths, polychaetes, heteropods and salps the entire body length was measured. Head and tail dimensions combined were recorded for larvaceans. Measurements of most plankton organisms were of maximum body dimension exclusive of spines, bristles or soft part extensions from shells or tentacles because of the difficulty of basing size-weight curves on such variable characteristics.

Polychaetes - the Alciopidae in particular - were usually incomplete, and most siphonophores were measured as individual bracts, the majority of which were fragmented from calycophoran or physonect colonies. The prey sizes determined from plankton samples, then, did not in such instances represent the exact dimensions of live plankton and may have in varying degrees underestimated the size of the prey as seen by the predator.

The plankton samples from the $300-350 \mathrm{~m}$ zone were analyzed in the above manner to provide an approximation of prey availability and size distribution. The total number of animals counted and identified from aliquots ranged from 310 to 476 and the number of length measurements from 310 to 399.

\section{ABUNDANCE AND VERTICAL DISTRIBUTION}

The essential characteristics of the vertical distribution of Valenciennellus tripunctulatus can be discerned from data in Table 1 . Three stations (III, IV, V) in the eastern Gulf of Mexico (Fig. 2) are represented by multiple trawl samples and most of the data were obtained from $27^{\circ} \mathrm{N} 86^{\circ} \mathrm{W}$. This is a station (V) which has been subjected to extensive sampling from the surface to $1000 \mathrm{~m}$ by discrete depth trawling for a number of years. The samples listed are only those in which $V$. tripunctulatus was taken; 32 tows within the expected time/depth range of $V$. tripunctulatus did not take this species.

One station (III) within the Central or Loop Current gyre, defined by the $22^{\circ} \mathrm{C}$ isotherm between 150 and $200 \mathrm{~m}$ depth (Leipper, 1970; Jones, 1973), was occupied at different seasons in conjunction with investigations of deep sound scattering layers. For

Table 1. Data for trawl collections in which Valenciennellus tripunctulatus occurred. L-C: Loop Current - Caribbean Water; $T$ : Transitional Water

\begin{tabular}{|c|c|c|c|c|c|c|c|c|}
\hline Station & Tow & Location & Date & Local time & $\begin{array}{l}\text { Depth } \\
\text { (m) }\end{array}$ & $\begin{array}{l}\text { Water } \\
\text { mass }\end{array}$ & $\begin{array}{l}\text { No. } \\
\text { fish }\end{array}$ & $\begin{array}{c}\text { Fish } \\
\left(10^{4} \mathrm{~m}^{3}\right)^{-1}\end{array}$ \\
\hline I & M112 & $13^{\circ} 18^{\prime} \mathrm{N} ; 67^{\circ} 01^{\prime} \mathrm{W}$ & $03 / 17 / 72$ & $0927-1100$ & $380-550$ & $\mathrm{~L}-\mathrm{C}$ & 7 & 3.93 \\
\hline \multirow[t]{3}{*}{ II } & M114 & $20^{\circ} 00^{\prime} \mathrm{N}_{;} 86^{\circ} 00^{\prime} \mathrm{W}$ & $03 / 22 / 72$ & $2021-2230$ & $460-500$ & $\mathrm{~L}-\mathrm{C}$ & 9 & 4.76 \\
\hline & M118 & $20^{\circ} 00^{\prime} \mathrm{N}_{;} 86^{\circ} 00^{\prime} \mathrm{W}$ & $03 / 25 / 72$ & $1318-1515$ & $490-530$ & $\mathrm{~L}-\mathrm{C}$ & 14 & 4.78 \\
\hline & M123 & $20^{\circ} 00^{\prime} \mathrm{N} ; 86^{\circ} 00^{\prime} \mathrm{W}$ & $03 / 26 / 72$ & $0254-0520$ & $400-590$ & $\mathrm{~L}-\mathrm{C}$ & 2 & 0.87 \\
\hline \multirow[t]{4}{*}{ III } & M 29 & $25^{\circ} 00^{\prime} \mathrm{N} ; 85^{\circ} 30^{\prime} \mathrm{W}$ & $06 / 13 / 71$ & $1442-1650$ & $400-420$ & $\mathrm{~L}-\mathrm{C}$ & 25 & 11.21 \\
\hline & M 31 & $25^{\circ} 00^{\prime} \mathrm{N} ; 85^{\circ} 30^{\prime} \mathrm{W}$ & $06 / 13 / 71$ & $0141-0306$ & $370-390$ & $\mathrm{~L}-\mathrm{C}$ & 18 & 10.91 \\
\hline & M 38 & $25^{\circ} 00^{\prime} \mathrm{N} ; 85^{\circ} 30^{\prime} \mathrm{W}$ & $06 / 14 / 71$ & $1058-1342$ & $500-580$ & $\mathrm{~L}-\mathrm{C}$ & 7 & 1.40 \\
\hline & M126 & $25^{\circ} 00^{\prime} \mathrm{N} ; 85^{\circ} 30^{\prime} \mathrm{W}$ & $03 / 27 / 72$ & $2121-0012$ & $310-390$ & $\mathrm{~L}-\mathrm{C}$ & 12 & 2.58 \\
\hline IV & M183 & $28^{\circ} 28^{\prime} \mathrm{N} ; 88^{\circ} 56^{\prime} \mathrm{W}$ & $08 / 21 / 73$ & $1145-1549$ & $360-500$ & $\mathrm{~T}$ & 16 & 2.61 \\
\hline \multirow[t]{14}{*}{ V } & J 2 & $27^{\circ} 00^{\prime} \mathrm{N} ; 86^{\circ} 00^{\prime} \mathrm{W}$ & $10 / 02 / 70$ & $1715-1846$ & $300-320$ & $\mathrm{~T}$ & 15 & 7.50 \\
\hline & J 16 & $27^{\circ} 00^{\prime} \mathrm{N} ; 86^{\circ} 00^{\prime} \mathrm{W}$ & $10 / 05 / 70$ & $1631-1931$ & $250-300$ & $\mathrm{~T}$ & 17 & 10.37 \\
\hline & $D 76$ & $27^{\circ} 00^{\prime} \mathrm{N} ; 86^{\circ} 00^{\prime} \mathrm{W}$ & $07 / 29 / 71$ & $1939-2210$ & $360-500$ & $\mathrm{~T}$ & 10 & 6.67 \\
\hline & B 135 & $27^{\circ} 00^{\prime} \mathrm{N} ; 86^{\circ} 00^{\prime} \mathrm{W}$ & $08 / 08 / 72$ & $1253-1718$ & $380-550$ & $\mathrm{~T}$ & 20 & 2.56 \\
\hline & B 142 & $27^{\circ} 00^{\prime} \mathrm{N} ; 86^{\circ} 00^{\prime} \mathrm{W}$ & $08 / 06 / 72$ & $0738-1058$ & $360-530$ & $\mathrm{~T}$ & 41 & 7.32 \\
\hline & B 143 & $2.7^{\circ} 00^{\prime} \mathrm{N} ; 86^{\circ} 00^{\prime} \mathrm{W}$ & $08 / 06 / 72$ & $1935-2210$ & $280-340$ & $\mathrm{~T}$ & 30 & 6.65 \\
\hline & B 149 & $27^{\circ} 00^{\prime} \mathrm{N} ; 86^{\circ} 00^{\prime} \mathrm{W}$ & $08 / 08 / 72$ & $0748-0956$ & $300-400$ & $\mathrm{~T}$ & 8 & 1.95 \\
\hline & B 152 & $27^{\circ} 00^{\prime} \mathrm{N} ; 86^{\circ} 00^{\prime} \mathrm{W}$ & $08 / 09 / 72$ & $2358-0403$ & $400-460$ & $\mathrm{~T}$ & 14 & 2.03 \\
\hline & M157 & $27^{\circ} 00^{\prime} \mathrm{N} ; 86^{\circ} 00^{\prime} \mathrm{W}$ & $08 / 13 / 73$ & $1638-1907$ & $290-310$ & $\mathrm{~T}$ & 12 & 2.15 \\
\hline & M158 & $27^{\circ} 00^{\prime} \mathrm{N}_{;} 86^{\circ} 00^{\prime} \mathrm{W}$ & $08 / 14 / 73$ & $2252-0048$ & $290-320$ & $\mathrm{~T}$ & 21 & 5.36 \\
\hline & M159 & $27^{\circ} 00^{\prime} \mathrm{N} ; 86^{\circ} 00^{\prime} \mathrm{W}$ & $08 / 14 / 73$ & $0311-0517$ & $290-320$ & $\mathrm{~T}$ & 22 & 5.43 \\
\hline & B 208 & $27^{\circ} 00^{\prime} \mathrm{N}_{;} 86^{\circ} 00^{\prime} \mathrm{W}$ & $08 / 29 / 74$ & $1923-2218$ & $180-260$ & $\mathrm{~T}$ & 28 & 6.70 \\
\hline & B 207 & $27^{\circ} 00^{\prime} \mathrm{N}_{i} 86^{\circ} 00^{\prime} \mathrm{W}$ & $08 / 30 / 74$ & $0738-0949$ & $370-420$ & $\mathrm{~T}$ & 15 & 3.09 \\
\hline & C. 260 & $27^{\circ} 00^{\prime} \mathrm{N}_{;} 86^{\circ} 00^{\prime} \mathrm{W}$ & $06 / 06 / 76$ & $1700-1840$ & 300 & $T$ & 6 & 1.54 \\
\hline
\end{tabular}




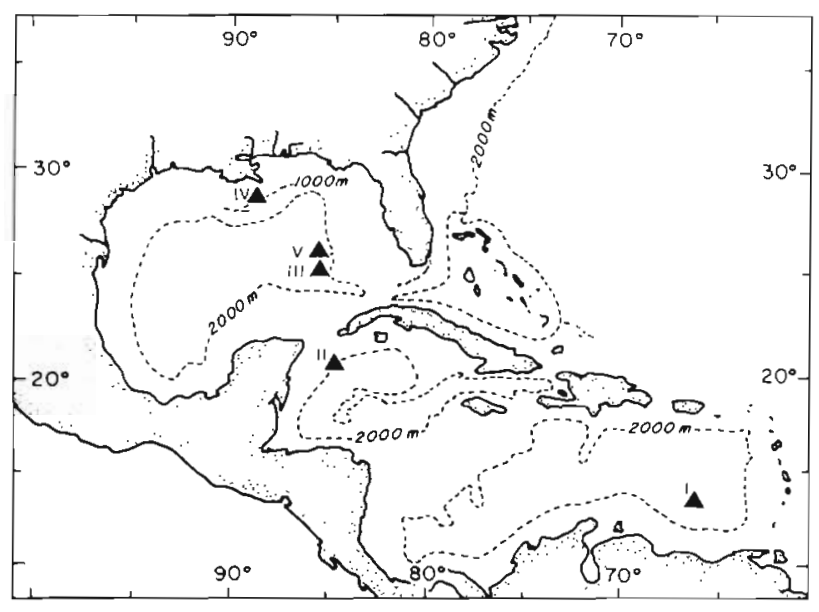

Fig. 2. Station locations in the Gulf of Mexico and Caribbean

comparative purposes data from two other locales (I, II) in the Caribbean are reported as well.

At $27^{\circ} \mathrm{N} 86^{\circ} \mathrm{W}$ (Standard Station) the $22^{\circ} \mathrm{C}$ isotherm is located well above $150 \mathrm{~m}$. However, both Loop (III) and Standard (V) Stations have characteristically low nutrient concentrations and consequently low rates of primary production ranging from $20-40 \mathrm{~g} \mathrm{C} \mathrm{m}^{-2} \mathrm{y}^{-1}$ (El-Sayed, 1972; Johansson et al., 1975; Hopkins, unpubl.). These production levels are typical of oligotrophic environments (Vinogradov, 1968; Ryther, 1969; McGowan, 1974).

Considering the Standard Station, Valenciennellus tripunctulatus appears to occupy a limited depth range both day and night. The species was taken from 250-550 $\mathrm{m}$ during the day with the highest densities occurring between 290 and $460 \mathrm{~m}$. A similar pattern was observed at night with positive samples occurring from $180-500 \mathrm{~m}$. There was little discernible difference in day/night distributions. The higher densities at night appeared to occur somewhat shallower than the highest daytime densities. If vertical migration does occur it is quite limited and the species appears broadly distributed over about $200 \mathrm{~m}$.

Within the Loop Current gyre Valenciennellus tripunctulatus occupies a similar depth range. However the data suggest that the species is concentrated somewhat deeper in the water column (370-550 m) with respect to Standard Station. Again day/night differences are not discernible. No individuals were taken above $370 \mathrm{~m}$ as compared to about $250 \mathrm{~m}$ at the Standard Station. Additional evidence is provided by data from trawl M126 (12 fish) in which most of the fishing time occurred at depths less than $370 \mathrm{~m}$. This tow, taken a day after the tows at $20^{\circ} \mathrm{N} 86^{\circ} \mathrm{W}$, was located near the Loop Current boundary in which the $22^{\circ} \mathrm{C}$ isotherm was found shallower than $150 \mathrm{~m}$ (ca $100 \mathrm{~m})$. The trawls from the northern Gulf of Mexico and Caribbean simply indicate that $V$. tripunctulatus occupies the same approximate depth zone at these locales as well.

There was little attempt to correlate fish length with depth of occurrence. Previous investigations have indicated that larger individuals tend to occur at somewhat greater depths and our data are not in conflict with this observation. The size distribution of fishes taken at various times of the year from March to October in the Gulf of Mexico did not reveal marked differences and little seasonal variation was discerned. The highest recorded density for a single tow was 11.21 fish $\left(10^{4} \mathrm{~m}^{3}\right)^{-1}$ and the mean for positive tows was 5 individuals $\left(10^{4} \mathrm{~m}^{3}\right)^{-1}$

The composite size distribution of the positive tows is depicted in Figure 3. It is apparent that small size

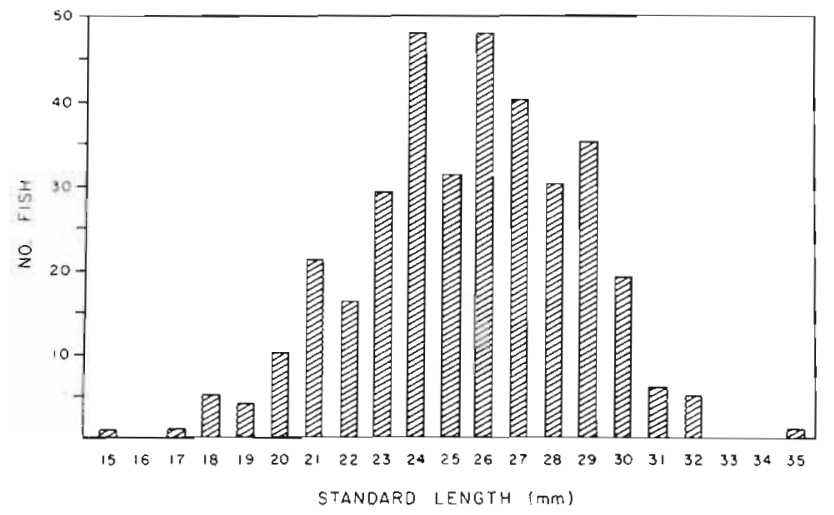

Fig. 3. Valenciennellus tripunctulatus. Size distribution of individuals taken in trawls listed in Table 1

classes are poorly represented. Larvae and small postlarvae less than about $12 \mathrm{~mm}$ standard length were not sorted. However, had individuals between 12 and $18 \mathrm{~mm}$ been abundant in trawl samples they would have been noted. Smaller size classes $(12-18 \mathrm{~mm})$ of other species (e.g. the myctophid Benthosema suborbitale) were often abundant in our catches.

The important distributional characteristics of Valenciennellus tripunctulatus can be summarized as follows: (1) There is at best a limited diel vertical migration within the upper mesopelagic zone (sensu Baird, 1971). (2) The species occupies a broad range within this zone (ca $250-500 \mathrm{~m}$ ) but depths of maximum concentration may well be more restricted. (3) Population densities appear low in comparison with more abundant mesopelagic species such as myctophids which migrate into the epipelagic zone. (4) There may exist a size-related pattern of vertical distribution in the Gulf of Mexico similar to that reported by other investigators. Our data, while suggestive, exhibit too much variance to statistically support this observation. 


\section{DIET COMPOSITION}

The data (Table 2) clearly indicate Valenciennellus tripunctulatus is primarily a predator on copepods with conchoecid ostracods being the only other plankton appearing in stomachs in any number. Of over 1900 prey items identified, all but 9 belong to these two groups. Euphausiids, while rare, numerically contributed about the same biomass as ostracods. The major prey taxa were members of the genus Pleuromamma, though a wide variety of other copepods were found in the diet as well.

There is little apparent difference in the kinds of prey found in stomachs of fishes taken either from within the Loop Current or in adjacent transitional environments (e.g. at Standard Station; Table 2). Variations which do occur derive at least in part from inequities in sample size, as three times more fish were examined from Transitional waters.

The size composition of prey taken from fishes caught in various locales and times in both the Gulf and Caribbean are presented in Figure 4. The same general pattern emerges from all sets of data in that most prey items are in the $1-4 \mathrm{~mm}$ range. The distributions are unimodal and skewed towards the smallest classes, the 1-2 $\mathrm{mm}$ size fraction being the largest. Prey biomass is also concentrated in the $1-4 \mathrm{~mm}$ range but with the maximum displaced toward larger size fractions within this range. Relatively few items larger than $4 \mathrm{~mm}$ were found in stomachs, though their biomass averaged over $15 \%$ of the total.

To investigate the role of ontogeny and change in fish size with respect to diet, a series of regression equations were calculated with standard lengths as the independent variable (Table 3). Individuals of Valenciennellus tripunctulatus examined in this study ranged from 15 to $35 \mathrm{~mm}$ (Fig. 3). No statistically significant $(F<0.05)$ regressions were obtained using either average or maximum number of prey items (or their appropriate transforms) as the dependent variable (Equations 1 and 2). Average prey biomass (Equation 4) yielded a significant regression at $F=0.05\left(\mathrm{r}^{2}\right.$ $=0.22$ ) while maximum prey biomass (Equation 3) was highly correlated $\left(r^{2}=0.86\right)$ with length. The

Table 2. Valenciennellus tripunctulatus. Taxonomic composition of identifiable stomach contents collected in the eastern Gulf and Caribbean. $\mathrm{N}$ in parentheses: number of fish examined. mgDW: $\mathrm{mg}$ dry weight

\begin{tabular}{|c|c|c|c|c|c|c|c|c|}
\hline \multirow[t]{2}{*}{ Prey item } & \multicolumn{4}{|c|}{ Transitional water $(\mathrm{N}=264)$} & \multicolumn{4}{|c|}{ Loop Current-Caribbean water $(\mathrm{N}=92)$} \\
\hline & No. & $\%$ & mgDW & $\%$ & No. & $\%$ & mgDW & $\%$ \\
\hline \multicolumn{9}{|l|}{ Copepods } \\
\hline Pleuromamma & 442 & 30.82 & 46.66 & 54.36 & 148 & 30.58 & 17.09 & 58.19 \\
\hline Unident. calanoids & 384 & 26.78 & 14.56 & 16.96 & 128 & 26.45 & 3.23 & 10.98 \\
\hline Oncaea & 222 & 15.48 & 0.34 & 0.40 & 17 & 3.51 & 0.05 & 0.17 \\
\hline Eucalanus & 90 & 6.28 & 3.67 & 4.28 & 14 & 2.89 & 0.49 & 1.67 \\
\hline Euchaeta & 47 & 3.28 & 5.74 & 6.69 & 27 & 5.58 & 2.15 & 7.32 \\
\hline Candacia & 39 & 2.72 & 3.46 & 4.03 & 28 & 5.78 & 1.77 & 6.03 \\
\hline Heterorhabdus & 20 & 1.40 & 0.92 & 1.07 & 8 & 1.65 & 0.27 & 0.92 \\
\hline Aegisthus & 19 & 1.32 & 0.20 & 0.23 & 6 & 1.24 & 0.03 & 0.10 \\
\hline Neocalanus & 18 & 1.26 & 2.71 & 3.16 & 4 & 0.83 & 0.77 & 2.62 \\
\hline Scolecithricella & 18 & 1.26 & 0.35 & 0.41 & - & - & - & - \\
\hline Euchirella & 16 & 1.12 & 3.87 & 4.51 & 5 & 1.03 & 0.50 & 1.70 \\
\hline Rhincalanus & 14 & 0.98 & 0.26 & 0.30 & 27 & 5.58 & 0.84 & 2.86 \\
\hline Lubbockia & 14 & 0.98 & 0.09 & 0.10 & 13 & 2.69 & 0.13 & 0.44 \\
\hline Clausocalanus & 12 & 0.84 & 0.15 & 0.17 & 3 & 0.62 & 0.03 & 0.10 \\
\hline Gaetanus & 9 & 0.63 & 0.27 & 0.32 & 1 & 0.21 & 0.06 & 0.20 \\
\hline Lucicutia & 4 & 0.28 & 0.15 & 0.18 & 4 & 0.83 & 0.07 & 0.24 \\
\hline Euaetideus & 4 & 0.28 & 0.10 & 0.12 & 5 & 1.03 & 0.17 & 0.58 \\
\hline Undeuchaeta & 3 & 0.21 & 0.48 & 0.56 & 1 & 0.21 & 0.17 & 0.58 \\
\hline Corycaeus & 3 & 0.21 & 0.01 & 0.01 & 1 & 0.21 & 0.01 & 0.03 \\
\hline Conaed & 2 & 0.14 & 0.01 & 0.01 & - & - & - & - \\
\hline Scottocalanus & 1 & 0.07 & 0.18 & 0.21 & - & _- & _- & - \\
\hline Spinocalanus & 1 & 0.07 & 0.05 & 0.06 & - & - & - & - \\
\hline Oithona & 1 & 0.07 & 0.01 & 0.01 & - & - & - & - \\
\hline Phyllopus & - & - & - & - & 1 & 0.21 & 0.07 & 0.24 \\
\hline \multicolumn{9}{|l|}{ Ostracods } \\
\hline Conchoecinae & 44 & 3.07 & 0.53 & 0.62 & 41 & 8.47 & 0.80 & 2.72 \\
\hline Euphausiids & 4 & 0.28 & 0.85 & 0.99 & 1 & 0.21 & 0.42 & 1.43 \\
\hline \multicolumn{9}{|l|}{ Amphipods } \\
\hline Vibilia & - & - & - & - & 1 & 0.21 & 0.25 & 0.85 \\
\hline Chaetognaths & 3 & 0.21 & 0.21 & 0.24 & - & - & - & - \\
\hline
\end{tabular}




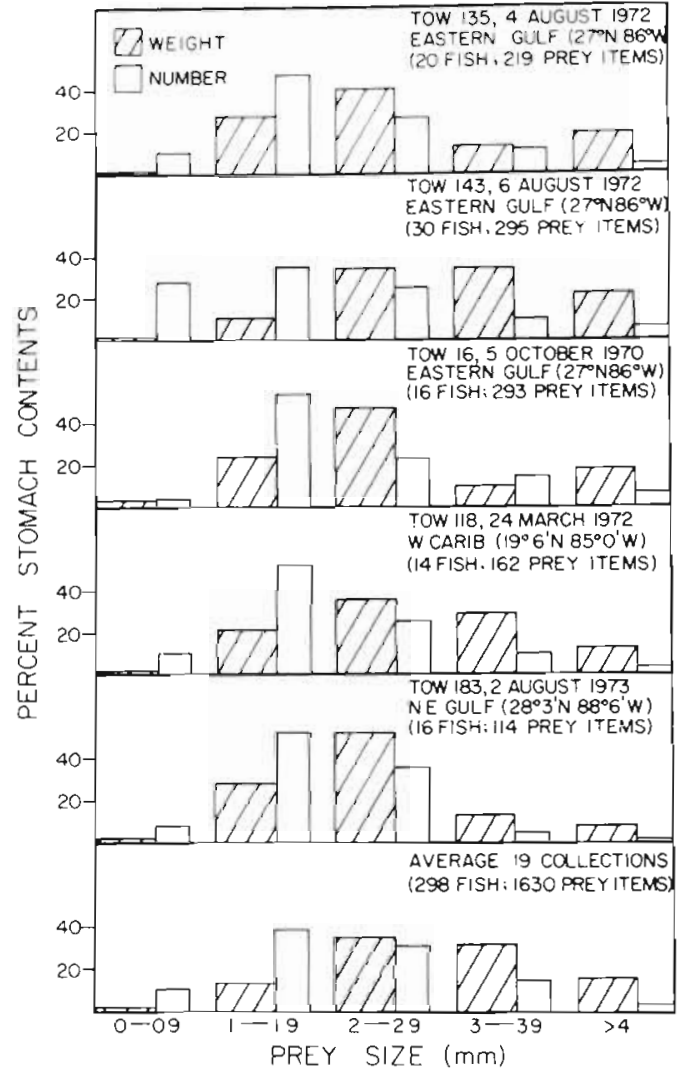

Fig. 4. Valenciennellus tripunctulatus. Geographic and seasonal variation in size distribution of prey items presence of near-empty stomachs in the data set for calculations using averages contributed to the high variability observed. Nevertheless, the data suggest that as $V$. tripunctulatus matures it meets energy demands by ingesting a greater percentage of larger prey instead of simply taking more food items in the daily ration. This is further supported by the significant positive relationships between fish length and both average prey size in stomachs and percentage of copepods larger than $3 \mathrm{~mm}$ (Equations 6, 7). The importance of Pleuromamma in the larger size fractions of food, and therefore in the diets of larger fish is indicated in Figure 5. This genus averaged over $80 \%$ of all copepods larger than $3 \mathrm{~mm}$ found in stomachs and while Pleuromamma numerically averaged only $31 \%$ of all diet items examined, it constituted $56 \%$ of total prey biomass. Considering the largest food items found in stomachs of each size class of fish, our data indicate that $V$. tripunctulatus begins ingesting significant numbers of copepods larger than $4 \mathrm{~mm}$ by the time it has attained a size of $23 \mathrm{~mm}$ SL (Fig. 5).

\section{FEEDING CHRONOLOGY AND DAILY RATION}

Our analyses show stomachs are fullest from approximately 1200 to $2200 \mathrm{~h}$ (Fig. 6). The last several hours of that period, depending on season and latitude, include twilight and a short span of darkness. Between

Table 3. Valenciennellus tripunctulatus. Regressions on fish standard length $\left(\mathrm{X}_{;} \mathrm{mm}\right)$ of various diet characteristics (Y). Regressions 1 and 2 were non-significant (N.S.), 4 was significant only to $F=0.05$. All other regressions were significant to at least $F<0.01$. Stomach and diet data are from fishes taken during period of most active feeding $(1200-2200 \mathrm{~h})$. Y values require the conversion indicated in the transformation column. "The number of fish examined is in column $X$ and the range of $Y$ values used in establishing the regression equations is in the $Y(\mathrm{rn})$ column. AFDW: ash-free dry weight; DW: dry weight

\begin{tabular}{|c|c|c|c|c|c|c|c|}
\hline No. & Dependent variable & $\begin{array}{l}\text { Regression } \\
\text { equation }\end{array}$ & $\begin{array}{l}\text { Transfor- } \\
\text { mation }\end{array}$ & $\begin{array}{l}\text { Coef. } \\
\text { det. } r^{2}\end{array}$ & $\begin{array}{c}\mathrm{Y} \\
(\mathrm{rn})\end{array}$ & $\begin{array}{c}X \\
(\text { No. })\end{array}$ & Comments \\
\hline 1 & $\begin{array}{l}\text { Avg. no. prey items per } \\
\text { stomach }\end{array}$ & N.S. & $(Y+0.5)^{\prime}=$ & 0.08 & $0-24$ & 195 & $\begin{array}{l}\text { Empty stomachs included } \\
\text { in average }\end{array}$ \\
\hline 2 & $\begin{array}{l}\text { Max. no. prey items per } \\
\text { stomach }\end{array}$ & N.S. & none & 0.27 & $9-24$ & 13 & $\begin{array}{l}\text { Based on stomachs with } \\
\text { most biomass in each fish } \\
\text { size class }\end{array}$ \\
\hline 3 & Fish biomass (mg AFDW) & $Y=0.116+0.061 X$ & $\log _{10} Y$ & 0.95 & $6.1-31.8$ & 6 & - \\
\hline 4 & $\begin{array}{l}\text { Avg. prey biomass in } \\
\text { stomachs (mgDW) }\end{array}$ & $Y=0.637+0.013 X$ & $(Y+0.5)^{\prime}=$ & 0.22 & $0-1.87$ & 195 & Empty stomachs included \\
\hline 5 & $\begin{array}{l}\text { Max. prey biomass in } \\
\text { stomachs (mgDW) }\end{array}$ & $Y=1.379+0.103 X$ & none & 0.86 & $0.57-1.87$ & 13 & $\begin{array}{l}\text { Based on stomachs with } \\
\text { most biomass in each fish } \\
\text { class }\end{array}$ \\
\hline 6 & $\begin{array}{l}\text { Avg. length of prey in } \\
\text { stomachs (mm) }\end{array}$ & $Y=0.83+0.59 X$ & none & 0.76 & $0.5-6.0$ & 72 & $\begin{array}{l}\text { Total copepod length } \\
\text { (metasome + abdomen) }\end{array}$ \\
\hline 7 & $\%$ prey $>3 \mathrm{~mm}$ in stomach & $Y=18.48+1.69 X$ & none & 0.79 & $11.5-40.6$ & 13 & - \\
\hline$\cdot \operatorname{Los}$ & \multicolumn{7}{|c|}{$\begin{array}{l}10 \text { Conversion was necessary for Regression } 3 \text { to normalize skewed data. The }(Y+0.5)^{\prime \prime 2} \text { transformation was used in } \\
\text { Regressions } 1 \text { and } 4 \text { because of the large number of zero values and the resulting skewness }\end{array}$} \\
\hline
\end{tabular}




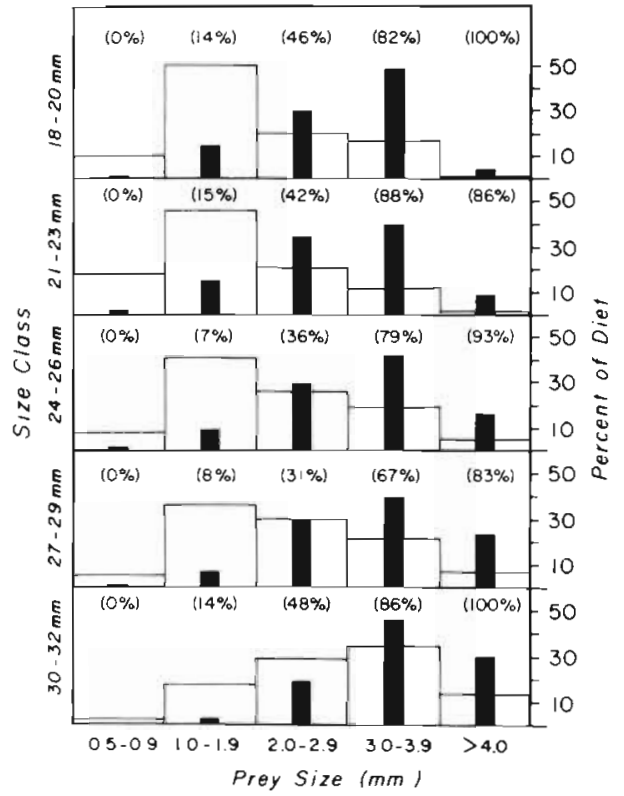

Fig. 5. Valenciennellus tripunctulatus. Size distribution of copepod prey in the diets of different size classes. Open bars: numbers; solid bars: biomass. Values in parentheses: numerical percentages of Pleuromamma spp. in diets

$2200 \mathrm{~h}$ and midnight, following a considerable residence time in the stomach, digested prey begins to appear in the intestine in significant quantities. From midnight through $0800 \mathrm{~h}$, the amount of material in stomachs continues to decrease and during that time intestines reach maximum fullness. In 0800-1200 h collections, small quantities of digested food were found in intestines while stomachs ranged from relatively empty to containing, in one sample, moderate amounts of food, indicative perhaps of early resumption of daylight feeding in some fishes.

During the period of most active foraging, fish were taken with empty stomachs and, conversely, fish captured between main feeding bouts often contained fresh prey. Assuming regurgitation and feeding in the trawl cod-end are not major sources of bias (Hopkins and Baird, 1975), it appears that the population is not feeding synchronously and individuals are not equally motivated or successful in obtaining forage during a diel feeding cycle. The mean number of prey items per stomach and per intestine for the period 1200-2200 h was compared with that of all other times combined. While skewness is apparent in the distributions, they are unimodal and a simple t-test was used for purposes of statistical inference. In both comparisons, the differences were highly significant $\{t<0.01\}$.

The average number of prey in stomachs collected in the period of active feeding was seven, irrespective of fish size. Maximum number of food items in stomachs considered full, also little correlated with size, ranged from 14-24 items ( $\bar{x}=20.5)$. Biomass of food in stomachs, however, was size-related and using the size-weight relationships for prey as described in Equations 4 and 5 (Table 3 ), it is possible to calculate an average and maximum biomass (back-calculated) of stomach contents for a given fish length. For example, average weight of stomach contents for individuals 15 and $30 \mathrm{~mm}$ in length is estimated at 0.19 and $0.31 \mathrm{mg}$ DW. Maximum weight of stomach contents for these two sizes would be 0.56 and $1.50 \mathrm{mg}$ DW, respectively. However, since the prey size-weight curves are based on formalin preserved material, the above ration values may be underestimates by as much as $15-30 \%$.

Valenciennellus tripunctulatus may feed at some non-zero level at all times. However, the relatively small numbers of prey in stomachs of fish collected in the least active period of the feeding cycle $(2200-0800 \mathrm{~h})$ and what appears to be considerable residence time of food in stomachs (Fig. 6) would argue

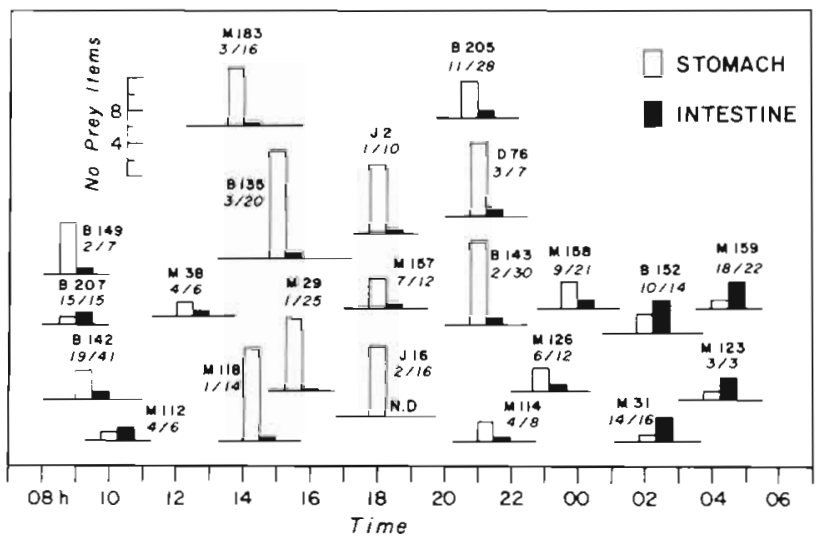

Fig. 6. Valenciennellus tripunctulatus. Diel feeding pattern as indicated by bar diagrams of number of prey items in stomachs and intestines. Values adjacent to each bar-set represent trawl number and fraction of stomachs with 3 or less items. Horizontal line under bars measures tow duration. N. D.: no data

that contribution to daily ration from 'snacking' between principal feeding bouts is insignificant.

The number and back-calculated biomass of prey items in the stomach at the end of the period of active feeding should approximate the daily ration. In the present instance, it was impossible to define precisely the end of the feeding period for any individual or the population as a whole. The population is not feeding in exact synchrony and average trawling time at depth was in excess of 90 min. Meaningful estimates of daily ration were be made, however, and two methods were used in the determination. Average ration was estimated by simply using averages calculated by pooling data from all individuals taken from 1200 to $2200 \mathrm{~h}$. This is considered a minimal estimate and in all likelihood underestimates actual mean daily ration.

Maximum ration was determined from those indi- 
viduals which contained the highest prey biomass in each fish length class. These individuals proportionally contained a relatively large percent of fresh prey and tended to occur later in the day. The regression equation (No. 5, Table 3) is highly significant and apparently represents an upper bound to stomach fullness for any given fish length $(r=0.86)$. Fish in this condition are unlikely to ingest significantly more items during the period of active feeding and the number and biomass of prey contained in these stomachs seems a reasonable measure of the daily ration for successfully foraging individuals. The maximum ration as measured here, however, probably overestimates the actual mean daily ration of the population as a whole. It is calculated from data obtained from the most successful foragers in the population and such individuals are relatively rare in the samples studied. The true mean daily ration likely lies between the average and maximum as calculated here. Estimated biomass of daily ration with respect to body weight can be calculated from Table 3, Equations 3, 4, and 5. Adjusting for intestinal contents (an average of two food items), the mean ration, for example, for 15 and $30 \mathrm{~mm} \mathrm{SL}$ is $3.9 \%$ and $1.4 \%$ body weight, respectively, and $5.6 \%$ and $3.1 \%$ on the basis of maximum ration (AFDW).

\section{DISCUSSION}

Our diet information is in general agreement with the findings of others for this species. For example, Merrett and Roe (1974) reported copepods and ostracods to be the principal forage of Valenciennellus tripunctulatus in the northwest Atlantic suggesting a basic consistency in the major elements of the diet regardless of oceanic region (see also Clarke, 1978). Further, our results were similar to those of Clarke (1978) and Roe (1974) concerning feeding chronology and the importance of Pleuromamma in the diet.

The back-calculation method used here for the determination of biomass is designed to correct for weight loss in prey items exposed for varying time periods to digestive processes. The assumption must be made that the principal prey taxa are rendered unrecognizable by digestion at approximately equivalent rates. Furthermore, in studies such as this, where individuals may remain in trawls some two hours or more, prey items cannot be rendered unrecognizable in stomachs over very short time periods. Gannon (1976), Clarke (1978) and others, have indicated that differential rates of digestion of various zooplankton could introduce bias in diet analysis and the former presented evidence on differences in the rates at which various cladoceran species become unrecognizable in stomachs of the alewife Alosa pseudoharengus.
Further, the predominant prey taxon reported here, the copepod genus Pleuromamma, is perhaps one of the most easily recognized in stomach analyses because of the persistence, even in the intestine, of the dark pigmented metasomal organ.

While varying rates of digestive decomposition among prey taxa probably do occur in Valenciennellus tripunctulatus, and there is evidence that to some degree this is true (e.g. from our observations euphausiids appear to decompose at a faster rate than copepods), there are a number of reasons which lead us to believe that the data on biomass and diet composition in Table 2 represent reliable estimates for the populations under study. These can be summarized as follows:

(1) The degree to which bias enters the data from differential digestion is determined in part by the length of time prey resides in the stomach. Individuals with stomach contents in well digested states are likely to produce the most biased estimates. In the present case, the great majority of prey items were from fishes taken during periods of active feeding. Much of the prey was easily recognizable, particularly as it was almost exclusively crustacean, and many items were classified as fresh or slightly digested. A comparison of fresh to slightly digested prey with well digested items (i.e. digestion categories 1 and 2 vs 5) revealed little difference in taxonomic composition and relative proportions of copepod genera. The only exception was a somewhat higher percentage in the unidentified calanoid' taxonomic category in the well digested fraction.

(2) Copepods, which constitute most of the diet of Valenciennellus tripunctulatus, have exoskeletons resistant to digestive processes and generic taxonomic characteristics persist, even at times in the intestines. Thus, separation of prey taxa in stomachs is usually good at least among copepods, and many genera other than Pleuromamma can be readily identified.

(3) Soft-bodied organisms such as larvaceans, salps, siphonophores and chaetognaths may be particularly vulnerable to rapid digestion and were not found to any extent in stomachs of Valenciennellus tripunctulatus. These forms have been identified and counted in diet analysis of other mesopelagic fishes and are important forage for a number of species. For example, larvaceans are a major component of the diet of the myctophid Diaphus taaningi from the Cariaco Trench and can be even identified in the intestine (Baird et al., 1975). Salps and siphonophores were recognizable and constituted $1 / 4$ of the food items in the stomachs of Ceratoscopelus warmingi, a myctophid characteristic of tropical-subtropical oceanic faunas (Hopkins and Baird, 1977). Cailliet (1972) recorded salps and larvaceans as the principal diet items of the bathylagid 
Lauroglossus stilbius in winter and spring in the Santa Cruz Basin off Southern California. In the present study, fishes which had predominantly fresh prey in stomachs contained no soft-bodied organisms. Since soft, non-crustacean prey can in some cases be recognized even in intestines in other midwater fishes, it is unlikely that these would escape detection in stomachs of $V$. tripunctulatus which have just recently fed.

In summary, we find no persuasive evidence which indicates serious bias is occurring from differential rates of prey decomposition.

The estimate for maximum ration, while perhaps an overestimate for the population as a whole, appears a reasonably accurate estimation of daily ration for successful foragers. The degree to which measurements of full stomachs approximate total daily ration ingested is dependent on several rate functions: ingestion rate, rate of digestive decomposition, and evacuation rate. Little is known of rate of ingestion which is partially a function of prey spatial distribution, and the perception and capture success of Valenciennellus tripunctulatus. Because of considerable variability in stomach fullness at all times in the period of active feeding, it does appear, however, that prey are ingested by individuals at irregular and non-synchronous intervals during the day, after which, in the case of full individuals, at least, feeding ceases. Likewise, there appears to be a long residence time for prey in stomachs and evacuation is not directly coupled with prey ingestion. Relatively little evacuation of intact prey items from stomach to intestine was detected during the daylight hours (Fig. 6), though the number of prey in stomachs, in general, increased during this time. It is only after the hours of heaviest feeding (1200-2200 h), that the number of prey items in intestines increases significantly. Thus the uncoupling of stomach filling and evacuation results in a buildup of prey items in the stomach apparently through much of the day. Stomach volume, then, can reach some maximum fullness depending on foraging success, and the daily ration can be estimated by direct measurement of stomach contents at maximum fullness. The observed uncoupling may be of considerable significance to the measurement of ingestion rates in mesopelagic zooplanktivores in that the degree of stomach fullness and its rate of evacuation undoubtedly affect satiation and feeding behavior.

Our maximum estimate of daily ration as a percentage of body weight is $5.6 \%$ for $15 \mathrm{~mm}$ fish and $3.7 \%$ for $30 \mathrm{~mm}$ SL individuals. These are comparable to that determined by Legand and Rivaton (1969) for the mesopelagic stomiatoid Vinciguerria nimbaria $(\sim 5 \%)$. Their percentages did not include intestinal contents, compensation for digestion or relate ration to body size on a dry weight basis. Recently Clarke (1978) attempted to measure daily ration in Valenciennellus tripunctulatus off Hawaii by estimating several digestive rate constants and assuming that stomach evacuation was proportional to this rate. His lower estimate of $4.3 \%$ is comparable to that measured here. Characteristically, younger (smaller) individuals tend to ingest proportionately more food per day than older fish, and this is reflected in the regressions in Table 3. In short, several lines of evidence are supportive of our estimates of daily ration and these form the basis for later studies of energetics and patterns of resource utilization.

Acknowledgements. This research was supported by NSF Contracts DES 75-03845 and OCE 75-03845. Information was also used from cruises supported by the Office of Naval Research and The Florida Institute of Oceanography. We wish to thank D. M. Milliken for his invaluable assistance in the sampling program and Drs R. H. Backus and J. E. Craddock, Woods Hole Oceanographic Institution, for reviewing an earlier version of this study.

\section{LITERATURE CITED}

Baird, R. C. (1971). The systematics, distribution and zoogeography of the marine hatchetfishes (family Sternoptychidae). Bull. Mus. comp. Zool. Harv. 142: 1-128

Baird, R. C., Hopkins, T. L., Wilson, D. F. (1975). Diet and feeding chronology of Diaphus taaningi (Myctophidae) in the Cariaco Trench. Copeia 1975: 356-365

Cailliet, G. M. (1972). The study of feeding habits of two marine fishes in relation to plankton ecology. Trans. Am. microsc. Soc. 91: 88-89

Clarke, T. A. (1978). Diel feeding patterns of 16 species of mesopelagic fishes from Hawaiian water. Fish. Bull. U. S. 76: $485-513$

Durbin, E. G., Durbin, A. G. (1978). Length and weight relationships of Acartia clausi from Narragansett Bay, R. I. Limnol. Oceanogr. 23: 958-969

El-Sayed, S. Z. (1972). Primary production and standing crop of phytoplankton. In: Bushnell, V. C. (ed.) Chemistry, primary productivity, and benthic algae of the Gulf of Mexico. Serial Atlas, Folio 22. American Geographical Society, New York

Gannon, J. E. (1976). The effects of differential digestion rates of zooplankton by alewife Alosa pseudoharengus, on determinations of selective feeding. Trans. Am. Fish. Soc. 105: 89-96

Hopkins, T. L. (1971). Zooplankton standing crop in the Pacific sector of the Antarctic. In: Ilano, G. A., Wallen, I. E. (eds) Biology of the Antarctic Seas, Vol. 17. American Geophysical Union, Washington, D. C., pp. 347-362

Hopkins, T. L., Baird, R. C. (1975). Net feeding in mesopelagic fishes. Fish. Bull. U. S. 73: 908-914

Hopkins, T. L., Baird, R. C. (1977). Aspects of the feeding ecology of oceanic midwater fishes. In: Anderson, N., Zahuranec, B. J. (eds) Proc. Int. Symp. Prediction of sound scattering in the ocean. Plenum Press, New York, pp. $325-360$

Hopkins, T. L., Baird, R. C., Milliken, D. M. (1973). A messenger-operated closing trawl. Limnol. Oceanogr. 18: $488-490$ 
Johansson, J. O. R., Gorman, M. E., Hopkins, T L. (1975). Phytoplankton productivity and standing crop in the Anclote River estuary in 1973-197. In: Mayer, G. F., Maynard, $V$ (eds) Anclote environmental project report 1974 to the Florida Power Corp., St. Petersburg, Fla., pp. 259-301

Jones, J. I. (1973). Physical oceanography of the northeast Gulf of Mexico and Florida continental shelf area. In: A summary of knowledge of the eastern Gulf of Mexico, Section IIB. Coord. by State University System of Florida Institute of Oceanography, pp. 1-11

Legand, M., Rivaton, J. (1969). Cycles biologiques des poissons mesopelagiques dan l'est de l'ocean Indien. Troisieme note: action predatrice des poissons micronectoniques Cahiers, Office de la recherce scientifique et technique outre-mer, oceanographie $7: 29-45$

Leipper, D. F. (1970). A sequence of current patterns in the Gulf of Mexico. J. geophys. Res. 75: 637-657

McGowan, J. A. (1974). The nature of ecosystems. In: Miller, C. C. (ed.) The biology of the oceanic Pacific, Proc. 33rd Ann. Biol. Colloq. Oregon State University Press, Corvallis, pp. 9-28

McGowan, J. A. (1977). What regulates pelagic community structure in the Pacific? In: Anderson, N., Zahuranec, B. J. (eds) Proc. Int. Symp. Prediction of sound scattering in the ocean. Plenum Press, New York, pp, 423-443

McGowan, J A., Walker, P. W. (1979). Structure in the copepod community of the North Pacific Central Gyre. Ecol. Monogr. 49: 195-226

Merrett, N. R., Roe, H. S. J. (1974). Patterns and selectivity in the feeding of certain mesopelagic fishes. Mar Biol. 28: $115-126$
Mullin, M. M., Evans, P. M. (1974). The use of a deep tank in plankton ecology. 2. Efficiency of a planktonic food chain Limnol. Oceanogr 19: 902-911

Omori, M. (1978). Some factors affecting dry weight, organic weight and concentrations of carbon and nitrogen in freshly prepared and in preserved zooplankton. Int. Revue ges. Hydrobiol. 63: 261-269

Roe, H. S. J. (1974). Observations on the diurnal vertical migrations of an oceanic animal community. Mar. Biol. 28: 99-113

Ryther, J. H. (1969). Photosynthesis and fish production in the sea. Science, N. Y. 166: 72-76

Sheldon, R. W., Sutcliffe, W. H., Paranjape, M. A. (1977). Structure of pelagic food chain and relationships between plankton and fish production. J. Fish. Res. Bd Can. 34: $2344-2353$

Steele, J. H. (1974). The structure of marine ecosystems, Harvard University Press, Cambridge

Vinogradov, M. E. (1962). Feeding of the deep sea zooplankton. Rapp. P.-v. Réun. Cons. perm. int. Explor. Mer 153: 114-119

Vinogradov, M. E. (1968). Vertical distribution of the oceanic zooplankton. IPST Translation, U. S. Department of Interior Document TT 69-59015, Washington, D. C., p. 339

Vinogradov, M. E., Menshutkin, V. V., Shuskina, E. A. (1972). On mathematical simulation of a pelagic ecosystem in tropical waters of the ocean. Mar. Biol. 16: 261-268

Weitzman, S. H. (1974). Osteology and evolutionary relationships of the Sternoptychidae, with a new classification of stomiatoid families. Bull. Am. Mus. Nat. Hist. 153: $327-478$

This paper was submitted to the editor; it was accepted for printing on January 7,1981 